\title{
Sıçanlarda Metotreksat ile İndüklenen Testis Hasarına Karşı E Vitamininin Koruyucu Etkileri: Histopatolojik ve Akım Sitometrik Çalışma
}

\section{Protective Effects of Vitamin E against Methotrexate-Induced Testicular Damage in Rats: Histopathologic and flow cytometric study}

\author{
Şeyma Kurt ${ }^{1}$, Züleyha Erişgin ${ }^{2 *}$, Yavuz Tekelioğlu ${ }^{1}$ Ahmet Ugur Akman ${ }^{1}$, Sibel Türedi ${ }^{3}$ \\ ${ }^{1}$ Karadeniz Teknik Üniversitesi, Tıp Fakültesi, Histoloji-Embryoloji AD., Trabzon, Türkiye \\ ${ }^{2}$ Giresun Üniversitesi, Tıp Fakültesi, Histoloji-Embryoloji AD., Giresun, Türkiye \\ ${ }^{3}$ Harran Üniversitesi, Tıp Fakültesi, Histoloji-Embryoloji AD., Ş. Urfa, Türkiye \\ seyma_biolog@hotmail.com,zerisgin@hotmail.com, ytekeli61@yahoo.com, aua11aua@hotmail.com, \\ sibelturedi3361@hotmail.com \\ Orcid: 0000-0002-5754-3757 \\ Orcid: 0000-0003-3523-6542 \\ Orcid:0000-0002-8757-0211 \\ Orcid:0000-0002-6031-9545 \\ Orcid:0000-0003-0946-0700 \\ *Sorumlu Yazar / Corresponding Author: Sorumlu Yazar: Züleyha Erişgin ${ }^{2}$ \\ Gönderim Tarihi / Received: 14.01.2020 \\ Kabul Tarihi / Accepted: 30.04.2020 \\ DOI: $10.34087 /$ cbusbed.674829 \\ $\ddot{O} z$
}

Giriş ve Amaç: Metotreksat oksidatif strese bağlı doku hasarına neden olmaktadır. E vitamini serbest oksijen radikallerinin etkisiyle oluşan lipit peroksidasyonunu nötralize eder. Bu çalışma ile E vitamininin olası metotreksat bağlantılı testiküler hasara karşı koruyucu etkileri analiz edildi.

Gereç ve Yöntemler: Otuz iki erkek Spraque dawley sıçan; metotreksat (MTX), E vitamini, MTX+ E vitamini ve kontrol olarak gruplandırıldı. İlk gün MTX grubuna intraperitoneal(i.p.) $20 \mathrm{mg} / \mathrm{kg}$ MTX, E vitamini grubuna 5 gün $100 \mathrm{mg} / \mathrm{kg}$ i.p. E vitamini, MTX+E vitamini grubuna ilk gün $20 \mathrm{mg} / \mathrm{kg}$ i.p. MTX ve 5 gün $100 \mathrm{mg} / \mathrm{kg}$ i.p. E vitamini uygulandı. Kontrol grubuna 5 gün $2 \mathrm{ml}$ serum fizyolojik (i.p.) uygulandı. Testiküler dokuda histopatolojik, akım sitometrik analizler yapıldı ve apopitoz değerlendirildi.

Bulgular: Apopitotik indeks (\%) ve testiküler hasar en fazla MTX grubundayken, MTX+E vitamini grubunda MTX grubuna göre anlamlı derecede azalma gözlendi. Seminifer tübül çapı MTX grubunda belirgin şekilde azalırken, $\mathrm{MTX}+\mathrm{E}$ vitamini grubunda MTX grubuna göre artış gözlendi. MTX ve MTX+E vitamini grupları arasında germinal epitelyum ve testiküler ağırlık sonuçları açısında anlamlı farklılık yoktu.

Sonuç: Sonuçlara göre MTX testislerde yapısal hasara neden olabilirken, E vitamini MTX'e bağlı testiküler hasarı düzeltebilir.

Anahtar Kelimeler: Akım sitometri, Apopitoz, E vitamin, Metotreksat, TUNEL

\begin{abstract}
Objective: Methotrexate (MTX) can cause oxidative stress-related tissue damage.Vitamin E neutralizes lipid peroxidation arising from the effect of free oxygen radicals.In this study, the protective effect of vitamin $\mathrm{E}$ against possible MTX-related testicular damage was analyzed.

Materials and Methods: Thirty two mature male Spraque dawley rats were grouped as MTX, Vitamin E, MTX+vitamin E and control groups. $20 \mathrm{mg} / \mathrm{kg}$ MTX intraperitoneal (i.p.) was applied to MTX Group in the first day; $100 \mathrm{mg} / \mathrm{kg}$ i.p. vitamin E was applied to vitamin E Group for 5 days; $20 \mathrm{mg} / \mathrm{kg}$ i.p. MTX in the first day and $100 \mathrm{mg} / \mathrm{kg}$ i.p. vitamin E for 5 days were applied to MTX+vitamin E Group;2 ml physiological saline solution (i.p.) was applied to control group for 5 days. Histopathology and flow cytometric analysis were done and apoptosis was evaluated on testicular tissue.

Results: Apoptotic Index (\%) and testicular damage were highest for MTX Group, and significant decrease was observed for MTX+vitamin E Group compared to MTX Group.Seminiferous tubule size significant decreased in MTX
\end{abstract}


Group and it increased in MTX+vitamin E Group compared to MTX Group. No significant difference was found between MTX and MTX+vitamin E Groups regarding germinal epithelium thickness and testicle weights.

Conclusion: The results show that MTX can cause structural disruptions in testicles and vitamin E can rehabilitate MTX-related testicular damage.

Keywords: Apoptosis, flow cytometry, Methotrexate, TUNEL, Vitamin E

\section{Giriş}

Methotrexate (MTX), a folic acid analogue, is used in the treatment of leukemia and solid organ malignancies such as head and neck, lung and uroepithelial tumors, and inhibits dihydrofolate reductase (DHFR) enzyme which is required for deoxyribonucleic acid [DNA] synthesis and cell division $[1,2,3,4]$. In this process, it transforms DHF into tetrahydrofolate (THF), and both purine and pyrimidine syntheses are thus reduced [2, 5]. MTX affects the purine and pyrimidine metabolisms and many other metabolic pathways that involve DNA synthesis. Therefore, MTX induces both medical and toxic effects [4]. Cytotoxic effect also plays a role on the tissues of which proliferation rate is high because it is not directly selective against cancer cells [1]. It is known that such adverse effects are due to the oxidative stress caused by reactive oxygen species [ROS] [6, 7, 8]. It has been reported to cause important toxic effects on several organs such as liver, kidneys, bone marrow and testicles $[9,10]$.

It has been reported to have adverse effects on reproductive system such as oligospermia and menstrual disorders, defects of oogenesis and spermatogenesis, abortus and teratogenicity $[4,11]$. The testicular toxicity effect of MTX can be direct or oxidative stress-induced [4]. Free radicals increase in consequence of chemotherapy and affect adversely spermatogenesis by causing damage to testicular tissue [apoptosis] $[12,13]$. Vitamin E is an oil-soluble and antioxidant vitamin [14]. Its active biological structure and most common form is alpha $(\alpha)$-tocopherol [14]. Alpha-tocopherol takes part in antioxidant defense mechanisms of the body in order to prevent the damages produced by reactive oxygen particles $[15,16]$, and precludes possible damages by binding oxygen. Vitamin E plays the most efficient role in the neutralization of lipid peroxidation incurred owing to the effects of free oxygen species [17]. It is demonstrated that vitamin $\mathrm{E}$ has a role in DNA synthesis and is influential in immune system in addition to its anticarcinogenic effects [18].

Apoptosis is defined as the programmed cell death that occurs under a certain genetic control. It ensures the continuity of cellular production-destruction balance and the programmed death of damaged cells in an organism [19]. Apoptosis is a basic process for morphogenesis and does not only occur during embryonic phase but also continues in adulthood stage [19].

A common characteristic of many species concerning spermatogenesis is that a majority of germ cells die by apoptosis during various stages of development. The subsistence or death of germ cells is determined by a very complex signal network. The proteins of Bcl-2 family form a signal pathway vital for germ cell homeostasis.
Certain members of this family [Bcl-2, Bcl-xL, Bcl-w, Mcl-1 and A1] conduct signals for the subsistence of a cell while certain other members (Bax, Bak and Bim) produce the opposite effect. Apoptosis is a crucial factor for the adjustment of germ cell numbers and of the proportion between germ cells and sertoli cells. It is not precise how much of the cells become subject to apoptosis. Germ cells that incur damage at any stage or cannot fulfill their development are selectively demolished by apoptosis. Therapies with radiation, toxicants and gonadotropin-releasing hormone $(\mathrm{GnRH})$ antagonist and heat and stress can accelerate apoptosis [20]. Although apoptosis in testicular tissue is accepted to be a normal process for development, the balanced perpetuation of it defines a healthy process. Increase in apoptosis is also another process which negatively affects fertilization [21].

In this study, we aimed to histopathologically analyze on the testicular tissue damaged by MTX, a widely-used chemotherapeutic medication, the morphometric results [such as seminiferous tubule epithelium and seminiferous tubule diameter] of short-term acute vitamin E application and its effects on apoptotic index.

\section{Materyal ve Metot}

In this study, 32 male Sprague-Dawley rats (200-250 g) taken from the Surgical Research Center of the Medical Faculty of Black Sea Technical University were used upon the permit (Date: 18.12.2013, Issue: 700) obtained from Local Ethics Committee for Animal Experiments of the Medical Faculty of Black Sea Technical University. The rats were kept under $22 \pm 2{ }^{\circ} \mathrm{C}$ and $\% 50 \pm 5$ humidity conditions, and were subject to 12 hours of light and darkness for each. The study groups were determined as follows:

1st Group (MTX Group): $20 \mathrm{mg} / \mathrm{kg}$ MTX i.p. was applied only on the first study day $(n=8)$. 2nd Group (vitamin E Group): $100 \mathrm{mg} / \mathrm{kg}$ vitamin E i.p. was given for five days during the study $(n=8)$. 3rd Group (MTX+vitamin E Group): $20 \mathrm{mg} / \mathrm{kg}$ MTX (i.p.) and 100 $\mathrm{mg} / \mathrm{kg}$ vitamin $\mathrm{E}$ (i.p.) were applied only on the first day and for 5 days during the study, respectively $(n=8) .4$ th Group (Control Group): Only normal saline was given for 5 days $(n=8)$. In the end of the experiment (at the end of 5th day), the rats were sacrificed by exsanguination while under anesthesia, their testicles were taken out and weighted. The right testicles were bisected, and halves were subjected to Bouin solution for histopathological examinations while the other halves were used for flow cytometry.

\subsection{Histopathological Processes}

The tissues were put into Bouin solution for histopathological examination and were made into 
paraffin-embedded blocks after tissue follow-up process. $5 \mu \mathrm{m}$ cross-sections were taken from these tissues for hemotoxilen-eosine staining. For the preparates; seminiferous tubule size, germinal epithelium thickness and immature germ cells in lumen were calculated under Olympus DP 71 (Japan) light microscope (LM) by using Analysis 5 Research (Olympus Soft Imaging Solution, Germany) software. Spermatogenetic cells and interstitial area in the seminiferous tubule were analyzed under Olympus BX51 (Japan) photomicroscope LM, and the pictures were digitalized. Johnsen scoring system was used for the evaluation of damage in testicle seminiferous tubule 22 .

\subsection{Immunohistochemical Processes}

Terminal deoxynucleotidyl transferase-mediated dUTP nick end labeling assay (TUNEL) (In Situ Cell Death Detection Kit, POD, Roche) was used on $5 \mu \mathrm{m}$ sections obtained from paraffin-embedded blocks and DNA fragmentations of germ cells in seminiferous tubules were defined. The homogenously stained TUNEL $(+)$ cells with brown nucleus which did not contain any necrosis area were evaluated as apoptotic cells. TUNEL positive cells were counted under 400x microscope (Olympus DP 71, Tokyo, Japan) using Analysis Research (Olympus Soft Imaging Solution, Germany) Program. For each testicle, TUNEL $(+)$ cell and total cell numbers were analyzed and Apoptotic percentage (Apoptotic Index $(\mathrm{AI})=$ TUNEL $(+)$ cell number $/$ total cell number $\mathrm{x}$ 100) was calculated in at least 10 seminiferous tubules 23.

\subsection{Flow Cytometric Analysis}

Testicular tissue samples were prepared in Coulter DNA Prep by subjecting them to DNA, LPR and DNA Stain solutions (coulter 6604451-54). After Coulter Epics Elite ESP Flow Cytometry device had been standardized with flow-check, each sample was exposed to 488nm argonion laser and the obtained DNA histograms were evaluated with Multicycle AV Phoenix flow system coulter analysis program.

\subsection{Statistical Analysis}

SPSS (Statistical Package for the Social Sciences version 13.1, SPSS Inc., Chicago, IL, USA) program and Microsoft $\AA$ Excel (for windows XP) were used in the statistical analysis of the data. The numerical data of each group were provided as mean \pm standard deviation (SD) and were compared to Kruskal Wallis variance analysis. $\mathrm{P}<0.05$ probability value was accepted to be significant in the comparison of all results.

\section{Results and Discussion}

\subsection{Apoptosis}

According to apoptotic index (AI, \%) results which had been evaluated with TUNEL method on the testicular tissues of experiment groups, MTX group had the highest $\mathrm{AI}(\%)$ value while control group had the lowest AI value among others. MTX and MTX+vitamin E groups were found to be statistically significant compared to control group. It was also revealed that AI value of MTX+vitamin E group decreased at a statistically significant level compared to MTX group (Tamhane test, $\mathrm{p}<0.001$ ). (Table 1, Figure 1a, 1b, 1c, 1d).

Table 1. Apoptotic Index (\%) of All Experiment groups

\begin{tabular}{|c|c|}
\hline Groups & Apoptotic Index (\%) \\
\hline MTX group $(n=8)$ & $16.92 * \pm 1.97$ \\
\hline $\begin{array}{l}\text { MTX+vitamin E group } \\
(\mathrm{n}=8)\end{array}$ & $9.89 * * \pm 1.01$ \\
\hline Vitamin E group $(n=8)$ & $3.09 \pm 0.32$ \\
\hline Control group $(n=8)$ & $2.01 \pm 0.29$ \\
\hline \multicolumn{2}{|c|}{$\begin{array}{l}\text { *: The results obtained from MTX group increased } \\
\text { significantly compared to other groups }(\mathrm{p}<0.05) \text {. } \\
\text { **: The value obtained from MTX+vitamin E group } \\
\text { decreased at a significant level compared to MTX } \\
\text { group. } \\
(\mathrm{p}<0.001) \text {. }\end{array}$} \\
\hline
\end{tabular}
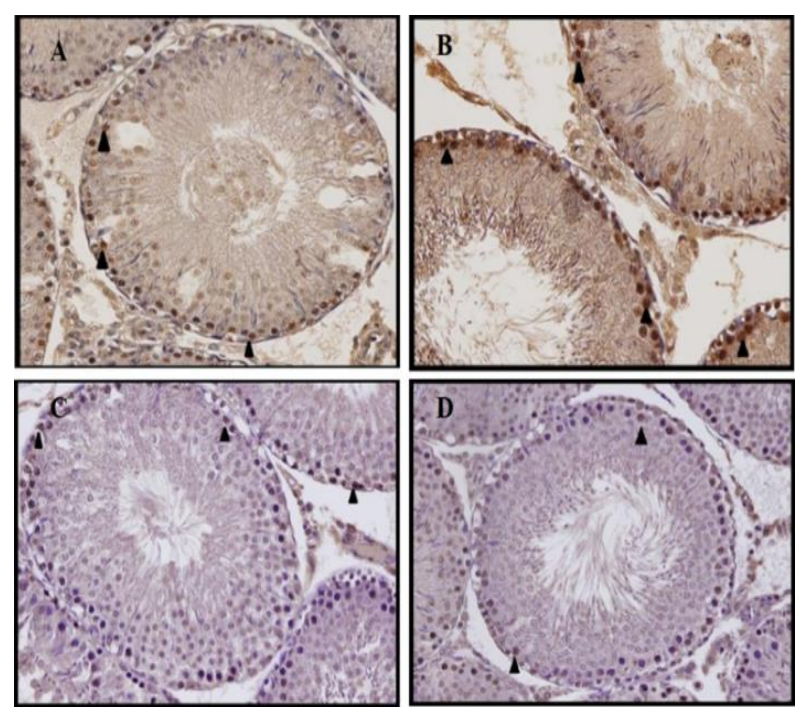

Figure 1. TUNEL (+) cell in the testicular tissues of the groups: A: MTX Group, B: MTX+Vitamin E Group, C: Vitamin E Group, D: Control Group (TUNEL, X400).

\section{Johnsen Scoring Results}

Testicular damage evaluation of the experiment groups was determined by Johnsen Scoring System. MTX+vitamin E group was found to have increased score at a statistically significant level compared to MTX group ( $\mathrm{p}<0.05$, Tamhane Test). The scoring results of control group were statistically significant higher than MTX and MTX+vitamin E groups ( $p<0.001$ for both, Tamhane Test). The difference between control group and vitamin $\mathrm{E}$ group was not significant (Table 2). 
Table 2. The Results of Johnsen Scoring System for the Experiment Groups

\begin{tabular}{|c|c|}
\hline Groups & $\begin{array}{l}\text { Johnsen Scoring } \\
\text { Results }\end{array}$ \\
\hline MTX group $(n=8)$ & $7.42 * \pm 0.46$ \\
\hline $\begin{array}{l}\text { MTX+vitamin E group } \\
(\mathrm{n}=8)\end{array}$ & $8.30 * * \pm 0.26$ \\
\hline Vitamin E group $(n=8)$ & $9.07 \pm 0.18$ \\
\hline Control group $(n=8)$ & $9.22 \pm 0.18$ \\
\hline \multicolumn{2}{|c|}{$\begin{array}{l}\text { *: The damage in MTX group increased at a significant level } \\
\text { compared to all the other groups }(\mathrm{p}<0.05) \text {. } \\
* * \text { The damage of MTX+vitamin E group decreased } \\
\text { significantly compared to MTX group }(\mathrm{p}<0.05) \text {. } \\
\text { MTX: Methotrexate }\end{array}$} \\
\hline
\end{tabular}

\subsection{Flow Cytometric Evaluation}

All groups' G0/G1, S and G2/M phase values of cell cycle were evaluated in percentages by cytometric analysis. According to the results obtained from MTX group, it was found out that $\mathrm{S}$ and $\mathrm{G} 2 / \mathrm{M}$ phase values increased compared to control group. It was also seen that the results of MTX+vitamin E group showed decreased in terms of S and G2/M phase values compared to MTX group (Table 3 ).

Table 3. The Results of Flow Cytometric Evaluation for the Experiment Groups

\begin{tabular}{|l|l|l|l|}
\cline { 2 - 4 } \multicolumn{1}{c|}{} & \multicolumn{3}{l|}{ Phase Values (\%) } \\
\hline Groups & $\begin{array}{l}\text { G0/G1 } \\
\text { Phase }\end{array}$ & S Phase & $\begin{array}{l}\text { G2/M } \\
\text { Phase }\end{array}$ \\
\hline $\begin{array}{l}\text { MTX group } \\
(\mathrm{n}=8)\end{array}$ & 93.4 & 3.5 & $3.1 *$ \\
\hline $\begin{array}{l}\text { MTX+vitamin E } \\
\text { group (n=8) }\end{array}$ & 96.8 & 1.8 & $1.4 * *$ \\
\hline $\begin{array}{l}\text { Vitamin E group } \\
\text { (n=8) }\end{array}$ & 98.4 & 0.9 & 0.7 \\
\hline $\begin{array}{l}\text { Control group } \\
\text { (n=8) }\end{array}$ & 98.5 & 0.8 & 0.7 \\
\hline $\begin{array}{l}\text { *: Compared to Control group, the percentage of S and G2/M } \\
\text { phase values of MTX group were observed to have increased. } \\
\text { **: Compared to MTX group, the percentage of S and G2/M } \\
\text { phase values of MTX+vitamin E group were found to have } \\
\text { decreased. } \\
\text { MTX: Methotrexate }\end{array}$ \\
\hline
\end{tabular}

\subsection{Results Concerning Seminiferous Tubule Diameter and Germinal Epithelium Thickness}

According to the statistical results obtained from seminiferous tubule diameter, the results of MTX group decreased at a statistically significant level compared to all the other groups. However, the results of MTX+vitamin E group increased significantly compared to MTX group (Tamhane Test, $\mathrm{p}<0.05$ ). The differences between control group and vitamin $\mathrm{E}$ group and between control group and MTX+vitamin E group were not statistically significant (Tamhane Test, $\mathrm{p}=0.996$ for vitamin $\mathrm{E}$ group, $\mathrm{p}=0.377$ for $\mathrm{MTX}+$ vitamin $\mathrm{E}$ group).
According to the statistical results obtained from germinal epithelium thickness, the difference between the results of MTX group and MTX+vitamin E group was not statistically significant (Tukey HSD, $\mathrm{p}<0.143$ ). MTX group demonstrated decrease at a significant level compared to control group (Tukey HSD, $\mathrm{p}<0.001$ ). While vitamin E group did not show statistically significant difference compared to control group (Tukey HSD, $\mathrm{p}=0.615$ ), all the other groups showed significant decrease compared to the same (Table 4).

Table 4. The Average Values of Morphometric Measurements of Experiment Groups

\begin{tabular}{|c|c|c|}
\hline Groups & $\begin{array}{l}\text { Seminiferous } \\
\text { Tubule Size } \\
(\mu \mathrm{m})\end{array}$ & $\begin{array}{l}\text { Germinal } \\
\text { Epithelium } \\
\text { Thickness } \\
(\mu \mathrm{m})\end{array}$ \\
\hline $\begin{array}{l}\text { MTX group } \\
(\mathrm{n}=8)\end{array}$ & $242.03^{a} \pm 10.45$ & $64.33 * \pm 5.51$ \\
\hline $\begin{array}{l}\text { MTX+vitamin E } \\
\text { group }(n=8)\end{array}$ & $264.79^{b} \pm 9.37$ & $69.49 \pm 6.11$ \\
\hline $\begin{array}{l}\text { Vitamin E group } \\
(\mathrm{n}=8)\end{array}$ & $271.15 \pm 2.00$ & $79.45 \pm 3.39$ \\
\hline $\begin{array}{l}\text { Control group } \\
(\mathrm{n}=8)\end{array}$ & $271.81 \pm 2.79$ & $82.31 \pm 2.72$ \\
\hline \multicolumn{3}{|c|}{$\begin{array}{l}\text { a: The values of MTX group decreased at a statistically significant } \\
\text { level compared to all the other groups ( }<<0.05) \text {. } \\
\text { b: The values of MTX+vitamin E group increased significantly } \\
\text { compared to MTX group ( }<0.05 \text { ). } \\
\text { *: The values of MTX group decreased significantly compared to } \\
\text { Control group ( }<<0.001) \text {. } \\
\text { MTX: Methotrexate }\end{array}$} \\
\hline
\end{tabular}

\subsection{Histopathological Evaluations}

When we analyzed the testicular tissues histopathologically, we found out for the control group rats that germinal cells of the spermatogenic series in seminiferous tubules had a normal cycle, the integrity of the interstitial area tissue and leydig cells were preserved (Figure 2a, 3a). It was observed that there were a great number of immature germ cells in the lumen of seminiferous tubules of MTX group and that there were irregular dilatation of basal membrane, edema in the intertubular area and vacuolization in germinal epithelium in places (Figure 2c, 3c). It was also seen in the seminiferous tubules of MTX+vitamin E group the vacuolization decreased notably, and that the structure of spermatogenic cells and the integrity of germinal epithelium were preserved (Figure 2d, 3d). It was discovered that the spermatogenic cell cycle in the seminiferous tubules of vitamin $\mathrm{E}$ group was normal similar to that of control group, and the integrity of tubular structure and of intertubular area were preserved (Figure 2b, 3b).

Our study revealed that systemic MTX application increased apoptosis and damage in the testicular tissue of rats, caused decrease in seminiferous tubule diameter but did not lead to any change on epithelium thickness and testicular weight. Besides, MTX+vitamin E application decreased apoptosis rate and testicular damage, increased seminiferous tubule size; however, it did not cause any 
change of germinal epithelium and testicular weight. MTX inhibits high doses of thymidylate synthesis and also prevents DNA synthesis as the most characteristic toxicity effect $[24,25]$. It is reported to trigger apoptotic induction for it increases oxidative stress and caspase-3 levels even in the lowest concentrations [23].
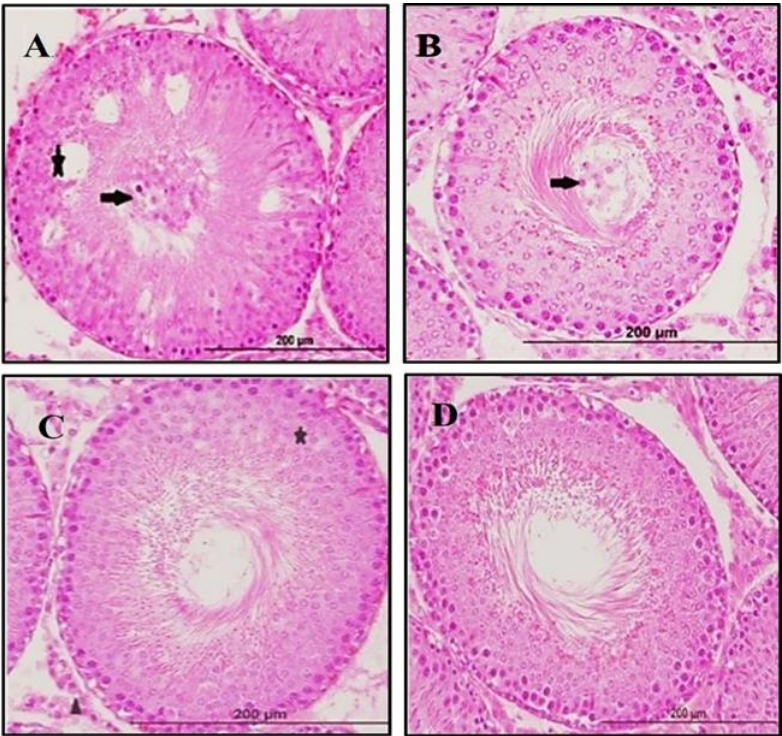

Figure 2. Seminiferous Tubule of All Groups.

A: MTX Group, B: MTX+Vitamin E Group, C: Vitamin E Group, D: Control Group (H\&E, x400).

A: Seminiferous Tubules: $\hat{\wedge}$ Interstitial Tissue: $\mathrm{C}$ : Vacuolization in Seminiferous Tubules: $\boldsymbol{\lambda}$, Immature Germ Cells in Lumen:

D: Immature Germ Cells in Lumen:
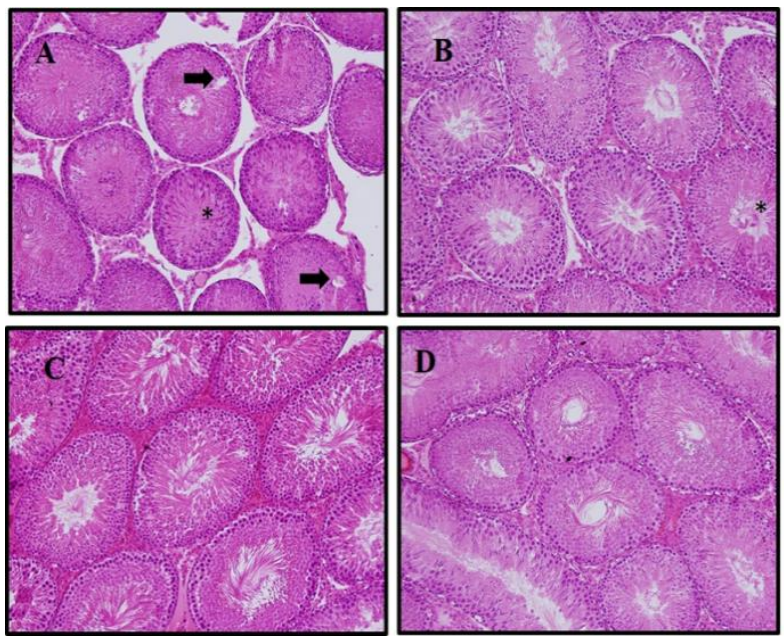

Figure 3. Testicular Sections of All groups.

A: MTX (Vacuol: $\square$, close lumen: *), B: MTX+Vitamin E (Immature cell: *), C: Vitamin E, D: Control, (H\&E, $\mathrm{x} 200)$.

It is also known that chemotherapeutic agents affect p53 gene activation mechanism and thus induce apoptosis [26]. MTX-induced organ toxicity is believed to originate due to oxidative stress $[27,28,29,30]$, and it is reported that a single dose of MTX leads to oxidative stress in rat testicles [4].

Spermatogenic cells and, in particular, spermatocytes are highly sensitive against toxic agents. Systemic diseases, infections, antimetabolites and chemotherapeutic medications are some of the factors that affect spermatogenesis. Such agents decrease sperm formation and may lead to chromosomal and morphological anomalies [20]. Though apoptosis is observed in testicular tissue during developmental process, a healthy process requires a balanced apoptosis. An increase in apoptosis is also a process that affects fertilization [21]. Antioxidants are mechanisms that prevent the damage incurred by cells due to reactive oxygen species and inhibit their interaction with DNA by eliminating free radicals [31, 32]. Vitamin $\mathrm{E}$ is fat-soluble and natural antioxidant which takes place in biological membranes, inhibits oxidative stress and limits the activities of superoxide and lipid peroxide in membranes [33, 34, 35, 36]. Studies reported that vitamin E is an antioxidant which protects sperm cells from lipid peroxidation and oxidative stress [37].

Sönmez et al [27], Sheikhbahaei et al [28], Dagguli et al [29], Barbisan et al. [24], Vardi et al [30] revealed that MTX use may trigger apoptosis by increasing oxidative stress. We used TUNEL method in our study in order to evaluate apoptosis. According to the results, we observed that the AI results of spermatogenic cells of MTX group increased at a statistically significant level compared to control group, and that the AI results of MTX+vitamin E group decreased at a statistically significant level. The results we acquired demonstrated that MTX had an inductive effect for apoptosis and that, in this respect, our study supported the research performed by Barbisan et al. [24].We identified that TUNEL [+] cell involvement in MTX+vitamin E group decreased at a significant level compared to MTX group. Such result makes us consider that vitamin $\mathrm{E}$ may be effective against this toxicity where MTX induces apoptosis

Flow cytometry is one of the methods which enable researchers to obtain objective information by fast, reliable and large number of cell counting concerning proliferative activity and DNA content. Thus relative size, relative granularity and relative fluorescence density can be measured in cells. In our study, G0/G1, S and $\mathrm{G} 2 / \mathrm{M}$ phase values of cell cycles of all groups were analyzed in percentage and by flow cytometric analysis. We did not find any difference between control group and Vitamin $\mathrm{E}$ group in terms of proliferation index. $\mathrm{S}$ and G2/M phase values of MTX group were found to increase compared to control group and vitamin E group. The comparison of MTX+vitamin E group to MTX group showed that there was a decrease in both proliferation index and $\mathrm{S}$ and G2/M phase values. These results lead us to consider that if used alone, MTX increases mitotic proliferative activity; and that vitamin $\mathrm{E}$ has a curative effect against such activity.

According to our results of morphometric evaluation, MTX caused decrease in seminiferous tubule diameter at a significant level while it did not result in a significant 
level in germinal epithelium. It was also found out that MTX+vitamin E application increased seminiferous tubule diameter at a significant level compared to MTX but did not create a significant difference for germinal epithelium. In parallel with our study, the studies performed by Nouri et al. [38], Gökçe et al. [39] and Saxena et al. [40] indicated that both germinal epithelium thickness and seminiferous tubule diameter incurred decrease.

Morphological evaluations revealed that MTX resulted in certain damages to seminiferous tubules of testicles. The evaluations we carried out under light microscope suggested that immature germinal epithelium and germinal epithelium integrity in seminiferous tubule could not be preserved in the lumen of seminiferous tubule, and there were vacuoles and dilatations in germinal epithelium. MTX can cause deterioration to the integrity of testicular tissue and such damages may decrease the quality of spermatogenesis. Shrestha et al. [37] specified in a study that they observed decrease in seminiferous tubule diameter, dilatation in interstitial area and deterioration in the morphology of leydig cells due to MTX use. The study made on rats by Padmanabhan et al. [9] identified that MTX decreased sperm numbers to a large extent, increased sperm head anomalies and caused toxicity. For this reason, the results we acquired support the ones obtained by Shretha et al.[37] and Padmanabhan et al.[9] as well as the studies performed by Nouri et al. [38]. In respect to MTX+vitamin E exposure, it was found that vacuolization decreased to a certain extent compared to MTX group and that the structure of spermatogenic cells was preserved in the lumen of seminiferous tubules save for a couple of germinal epithelium cells. In relation to vitamin E, Shirpoor et al. [41] found out that vitamin E supplement cured structural changes in testicles which had been caused by the toxicity due to Ethanol application and ameliorated oxidative stress markers and gonadotropin hormone levels. In this sense, the results we obtained support the study performed by Shirpoor et al. [41].

In the comparison of testicular weights of all groups, we did not find any statistically significant difference $[p=0.63$ ]. Armagan et al. [42] also found similar results to our study. Differently, Padmanabhan et al. [9] and Nouri et al. [38] reported that MTX caused testicular and body weight decrease; Yuncu et al. [43] revealed that MTX led to testicular weight decrease and vitamin E could not rehabilitate such result.

\section{Conclusion}

As a result, MTX is used for treatment purposed but causes histopathological damage to testicular tissue. However, it is also revealed that short term [5 days] vitamin $\mathrm{E}$ application can prevent such damage. It is believed that more positive results can be obtained if vitamin $\mathrm{E}$ dosage is improved and application time is extended.

\section{References}

1. Panetta, JC, Sparreboom, A, Pui, CH, Relling, MV, Evans, WE, Modeling mechanisms of in vivo variability in methotrexate accumulation and folate pathway inhibition in acute lymphoblastic leukemia cells, PLoS Computational Biology, 2010, 2, 6(12), e1001019, doi: 10.1371/journal.pcbi.1001019.

2. Chabner, B, Wilson, W, Supko, J. Pharmacology and toxicity of antineoplastic drugs, Editorial: Lichtman, MA, Beutler, E, Seligsohn U, Kipps, TJ, Kaushansky, K, In Williams Hematology, 7th Edition. Mc Graw Hill Company, United States, 2007, 249-51.

3. Van Ede, AE, Laan, RF, Blom, HJ, De Abreu, RA, Van De Putte, LB, Methotrexate in rheumatoid arthritis: an update with focus on mechanisms involved in toxicity, Seminars in Arthritis and Rheumatism, 1998, 27, 277-292.

4. Jollivet, J, Cowan, K, Curt, G, Clendeninn, N, Chabner, B. The pharmacology and clinical use of methotrexate, The New England Journal of Medicine, 1983, 309, 1094-1104.

5. Dutz, JP, Ho, VC, Immunosuppressive agents in dermatology, Dermatologic Clinics, 1998, 16(2), 235-251.

6. Kolli, VK, Abraham, P, Isaac, B, Selvakumar, D, Neutrophil infiltration and oxidative stress may play a critical role in methotrexate-induced renal damage, Chemotherapy, 2009, 55(2), 8390.

7. Miyazono, Y, Gao, F, Horie, T. Oxidative stress contributes to methotrexate-induced small intestinal toxicity in rats, Scandinavian Journal of Gastroenterology, 2004, 39(11), 1119-27.

8. Jahovic, N, Çevik, H, Şehirli, AO, Yeğen, BC, Şener, G. Melatonin prevents methotrexate induced hepatorenal oxidative injury in rats, Journal of Pineal Research, 2003, 34(4), 282-287.

9. Padmanabhan, S, Tripathi, DN, Vikram, A, Ramarao, P, Jena, GB, Cytotoxic and genotoxic effects of methotrexate in germ cells of male Swiss mice, Mutation Research, 2008, 655(1-2), 59-67.

10. Olson, J, Klinik Farmakoloji. Birinci Baskı, Ankara, Hacettepe Taş Yayınc1lık, 2000.

11. Miketova P, Kaemingk, K, Hockenberry, M, Pasvogel, A, Hutter, J, Krull, K, Moore, IM, Oxidative changes in cerebral spinal fluid phosphatidylcholine during treatment for acute lymphoblastic leukemia, Biological Research For Nursing, 2005, 6 (3), 187-195.

12. Brunton, LL, Lazo, JS, Parker, KL, Goodman and Gilman's the pharmacologycal basis of therapeutics, Mc Graw- Hill Companies, 2006, New-York.

13. Bertram, G. Katzung, Basic and Clinical Pharmacology, 9. Edition, Singapore: The McGraw-Hill Companies, 2004; 898-931.

14. Işık, A, Işılay, L, Atabenli Erdemli, E, Akbay, C, Anafarta, K. Sıçan Testisinde Metotreksat'ın Işık Ve Elektron Mikroskop Düzeyinde Etkileri. Ankara Üniversitesi Tıp Fakültesi Mecmuası 1997; Cilt 50, Say1 3.

15. Oktar, S, Gokce, A, Aydin, M, Davarci, M, Meydan, S, Ozturk, OH, Koc, A, Beneficial effect of erdosteine on methotrexate-induced testicular toxicity in mice, Toxicology and Industrial Health, 2010, 26(7), 433-438.

16. Champe, PC, Biyokimya, Çeviren: Gür E, Nobel Tıp Kitabevi, İstanbul, 1997; 438 .

17. Pekiner, BD, Vitamin E as an antioxidant, Journal of Faculty of Pharmacy of Ankara University, 2003, 32, 243-267.

18. Leiber, DC, The role of metabolizm in the antioxidant function of vitamin E, Critical Reviews in Toxicology, 1993, 23, 147-169.

19. Nisbet, H, Nisbet, C, Akar, A, Cevik, M, Onder Karayigit, M. Effects of exposure to electromagnetic field $(1.8 / 0.9 \mathrm{GHz})$ on testicular function and structure in growing rats, Research in Veterinary Science, 2012, 93, 1001-1005.

20. Silva, AS, Villasenor, RMV, Marquez, SR, Gonzales, MH, Jaime, HB, Garcia, XG, Montiel, JLC. Testosterone levels and development 
of the penile spines and testicular tissue during the postnatal growth in Wistar Rats, Advances in Sexual Medicine, 2013, 3, 1-9.

21. Shen, H, Liao, K, Wu, HF, Lu, HC, Li, Y, Li, Z, Zhang, W. In utero exposure of high-dose di- n-butyl phthalate resulted in opposite effects on testicular cell apoptosis in late embryonic and pubertal male rat offspring. Human Experimental Toxicology, 2016, doi: $10.1177 / 0960327116685886$.

22. Rashed, M, Ragab, N, Shalaby, A, Ragab, W. Patterns Of Testicular Histopathology In Men With Primary Infertility, The Internet Journal of Urology, 2007, 5, 2.

23. Potten, CS, What is an apoptotic index measuring? A commentary. British Journal Cancer, 1996, 74(11), 1743-8.

24. Barbisan, F, Motta, Jde R, Trott, A, Azzolin, V, Dornelles, EB, Marcon, M, et al, Methotrexate-related response on human peripheral blood mononuclear cells may be modulated by the Ala16Val-SOD2 gene polymorphism, PLoS One, 2014, 9(10), e107299.

25. Oufi, HG, Al-Shawi, NN, The effects of different doses of silibinin in combination with methotrexate on testicular tissue of mice, Eurepan Journal of Pharmacology, 2014, 5, 730, 36-40.

26. Bangert, CA, Costner MI. Methotrexate in dermatology, Dermatologic Therapy, 2007, 20(4), 216-28.

27. Sönmez, MF, Çilenk, KT, Karabulut, D, Ünalmış, S, Deligönül, E, Öztürk, İ, Kaymak, E, Protective effects of propolis on methotrexateinduced testis injury in rat, Biomedicine \& Pharmacotherapy, 2016, 79, 44-51.

28. Sheikhbahaei, F, Khazaei, M, Rabzia, A, Mansouri K, Ghanbari A Protective Effects of Thymoquinone against Methotrexate-Induced Germ Cell Apoptosis in Male Mice, International Journal of Fertility and Sterility, 2016, 9(4),541-7.

29. Daggulli, M, Dede, O, Utangac, MM, Bodakci, MN, Hatipoglu, NK, Penbegul, N, et al, Protective effects of carvacrol against methotrexate-induced testicular toxicity in rats, International Journal of Clinical and Experimental Medicine, 2014, 15, 7(12), 5511-6. eCollection 2014.

30. Vardi, N, Parlakpınar, H, Ateş, B, Çetin, A, Otlu, A. Antiapoptotic and antioxidant effects of beta carotene against methotrexate-induced testicular injury, Fertility and Sterility, 2009, 92, 2028-33.

31. Abud-Mendoza, C, Martinez-Martinez, MU, Monsivais-Urenda, A, Gonzalez-Amaro, R, Laboratory biomarkers for guiding therapy with methotrexate in rheumatoid arthritis, Current Pharmaceutical Design, 2014, 21(2), 202-11.

32. Martin, SA, McCarthy, A, Barber, LJ, Burgess, DJ, Parry, S, Lord, $\mathrm{CJ}$, Ashworth, A, Methotrexate induces oxidative DNA damage and is selectively lethal to tumour cells with defects in the DNA mismatch repair gene MSH2, EMBO Molecular Medicine, 2009, 1(6-7), 32337.

33. Abbasi, MM, Khiavi, MM, Monfaredan, A, Hamishehkar, H, Seidi, K, Jahanban-Esfahlan, R, DOX-MTX-NPs augment p53 mRNA expression in OSCC model in rat: effects of IV and oral routes, Asian Pacific Journal of Cancer Prevention, 2014, 15(19), 8377-82.
34. Kalender, S, Uzun, FG, Demir, F, Uzunhisarcıkl1, M, Aslanturk, A, Mercuric chloride-induced testicular toxicity in rats and the protective role of sodium selenite and vitamin E, Food and Chemical Toxicology, 2013, 55, 456-62.

35. Ayinde, OC, Ogunnowo, S, Ogedegbe, RA, Influence of Vitamin C and Vitamin $\mathrm{E}$ on testicular zinc content and testicular toxicity in lead exposed albino rats, BMC Pharmacology and Toxicoogly, 2012, 13, 17.

36. Chen, H, Liu, J, Luo, L, Baig, MU, Kim, JM, Zirkin, BR, Vitamin E, aging and Leydig cell steroido genesis, Experimental Gerontology, 2005, 40(8-9), 728-36.

37. Shrestha, S, Dhungel, S, Saxena, AK, Bhattacharya, S, Maskey, D, Effect of methotrexate (MTX) administration on spermatogenesis: an experimental on animal model, Nepal Medical College Journal, 2007, 9(4), 230-3.

38. Nouri, HS, Azarmi, Y, Movahedin, M, Effect of growth hormone on testicular dysfunction induced by methotrexate in rats, Androloqia; 2009, 41(2), 105-10.

39. Gökçe, A, Oktar, S, Koç, A, Yonden, Z, Protective effects of thymoquinone against methotrexate-induced testicular injury, Human and Experimental Toxicology, 2011, 30(8), 897-903.

40. Saxena, AK, Dhungel, S, Bhattacharya, S, JHA, CB, Srivastava, AK, Effect Of Chronic Low Dose Of Methotrexate On Cellular Proliferation During Spermatogenesis In Rats, Archives of Andrology, 2004, 50, 33-35.

41. Shirpoor, A, Norouzi, L, Khadem-Ansari, MH, Ilkhanizadeh, B, Karimipour, M, The Protective Effect of Vitamin E on Morphological and Biochemical Alteration Induced by Pre and Postnatal Ethanol Administration in the Testis of Male Rat Offspring: A Three Months Follow-up Study, Journal of Reproductive Infertility, 2014, 15(3), 134-41.

42. Armagan, A, Uzar, E, Uz, E, Yilmaz, HR, Kutluhan, S, Koyuncuoglu, HR, Soyupek, S, Cam, H, Serel, TA, Caffeic acid phenethyl ester modulates methotrexate-induced oxidative stress in testes of rat, Human Experimental Toxicology, 2008, 27(7), 547-52.

43. Yuncu, M, Bükücü, N, Bayat, N, Sencar, L, Tarakçioğlu, M. The effect of vitamin $\mathrm{E}$ and L-carnitine against methotrexate-induced injury in rat testis, Turkish Journal of Medical Sciences, 2015, 45(3), 517-25.

http://edergi.cbu.edu.tr/ojs/index.php/cbusbed isimli yazarın CBU-SBED başlıklı eseri bu Creative Commons Alıntı-Gayriticari4.0 Uluslararası Lisansı ile lisanslanmıştır.

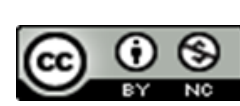

